\title{
PENERAPAN MODEL LEARNING CYCLE 5E UNTUK MENINGKATKAN KETERAMPILAN PROSES SAINS PESERTA DIDIK PADA MATERI GELOMBANG DI SMA NEGERI 1 SYAMTALIRA ARON
}

\author{
Nurlaila* \\ Guru SMA Negeri 1 Syamtalira Aron \\ *Korespondensi: nurlailaspd452@gmail.com
}

\begin{abstract}
Abstrak: Penelitian ini bertujuan untuk mendeskripsikan peningkatan keterampilan proses sains peserta didik dengan model Learning Cycle 5E pada materi gelombang berjalan dan gelombang stasioner di kelas XI MIA 1 SMA Negeri 1 Syamtalira Aron Tahun pelajaran 2018/2019. Desain penelitian ini adalah penelitian tindakan kelas yang berlangsung dalam dua siklus. Subjek penelitian terdiri dari 30 peserta didik kelas XI MIA 1 SMA Negeri 1 Syamtalira Aron yang terlaksana sebanyak dua siklus. Sebelum dilaksanakan siklus I peserta didik diberi tes awal (pra siklus), dan setelah itu dilaksanakan siklus I dan siklus II. hasil keterampilan proses sains pada siklus I pertemuan 1 memiliki krateria cukup baik sedangkan pada pertemuan 2 sampai dengan siklus II pertemuan 1 dan 2 mengalami peningkatan dengan kriteria baik. Berdasarkan hal tersebut, model pembelajaran Learning Cycle 5E dapat meningkatkan keterampilan proses sains peserta didik pada materi gelombang berjalan dan gelombang stasioner di kelas XI MIA 1 SMA Negeri 1 Syamtalira Aron Tahun pelajaran 2018/2019.
\end{abstract}

Kata Kunci: Keterampilan Proses Sains, Hasil Belajar Peserta didik, Model Pembelajaran Learning Cycle $5 e$

\section{IMPLEMENTATION OF THE CYCLE 5E LEARNING MODEL TO IMPROVE STUDENTS 'SCIENCE PROCESS ON WAVE MATERIALS AT SMA NEGERI 1 SYAMTALIRA ARON}

\begin{abstract}
This study aims to describe the improvement of students' science process skills with the 5E Learning Cycle model on the walking wave material and stationary waves in class XI MIA 1 SMA Negeri 1 Syamtalira Aron in the 2018/2019 academic year. The design of this research is a classroom action research which takes place in two cycles. The research subjects consisted of 30 students of class XI MIA 1 SMA Negeri 1 Syamtalira Aron which were carried out in two cycles. Before the first cycle, students were given a pre-cycle test, and after that, the first cycle and second cycle were carried out. The results of science process skills in the first cycle of meeting 1 have a pretty good criterion while at the second meeting to the second cycle meetings 1 and 2 have increased with good criteria Based on this, the Learning Cycle 5E learning model can improve students' science process skills on the walking wave and stationary wave material in class XI MIA 1 SMA Negeri 1 Syamtalira Aron for the 2018/2019 academic year.
\end{abstract}

Keywords: Science Process Skills, Student Learning Outcomes, Learning Models Learning Cycle $5 e$ 


\section{PENDAHULUAN}

Pendidikan adalah usaha sadar dan terencana untuk mewujudkan suasana belajar dan proses pembelajaran agar peserta didik secara aktif mengembangkan potensi dirinya untuk memilki kekuatan spiritual keagamaan, pengendalian diri, kepribadian, kecerdasan, akhlak mulia, serta keterampilan yang diperlukan dirinya, masyarakat, bangsa dan negara. Oleh karena itu, pembahasan dalam dunia pendidikan perlu dilakukan untuk mewujudkan pendidikan yang berkualitas. (Magfiroh, 2019) menyatakan bahwa untuk dapat mewujudkan pendidikan yang berkualitas, maka pengembangan pendidikan perlu dilaksanakan dengan berstandar pada empat pilar pendidikan sebagaimana yang telah direkomendasikan oleh UNESCO yaitu learning to know, learning to do, learning to be, dan learning to live together. Komponen pendidikan terdiri atas peserta didik, guru, dan interaksi keduanya dalam kegiatan pembelajaran.

Salah satu pelajaran pada Sekolah Menengah Atas adalah fisika. Fisika merupakan hasil dari kegiatan manusia berupa pengetahuan, gagasan, dan konsep yang terorganisasi tentang alam sekitar yang diperoleh dari pengalaman melalui serangkaian proses ilmiah. Proses ini meliputi penemuan masalah, perumusan masalah, pengajuan hipotesis, deduksi dari hipotesis, pengujian hipotesis dan penerimaan hipotesis menjadi teori ilmiah. Dari definisi tersebut dapat disimpulkan bahwa kegiatan pembelajaran fisika mencakup dua komponen yang tidak dapat dipisahkan yaitu proses dan produk. Proses adalah proses ilmiah yang langkah-langkahnya menggunakan prosedur atau metode ilmiah. Sedangkan produk adalah pengetahuan yang berupa fakta, konsep, prinsip, hukum, dan teori.

Pembelajaran fisika tidak hanya mengarah pada pemberian konsep dan prinsip saja, tetapi harus ada aspek keterampilan dan sikap peserta didik. Selain itu, dalam pembelajaran fisika juga tidak hanya mengarah pada produk fisika saja, tetapi juga mengarah pada proses fisika. Hal ini dikarenakan mempelajari fisika berarti memecahkan atau menemukan mengapa dan bagaimana peristiwa itu terjadi, sehingga peserta didik dapat dengan mudah menerapkan masalah fisika dalam kehidupan sehari-hari. Oleh karena itu pada proses pembelajaran fisika hendaknya peserta didik tidak hanya mendengarkan penjelasan guru akan tetapi peserta didik dituntut untuk mampu membangun pengetahuan dalam diri peserta didik dan berperan aktif selama proses pembelajaran.

Keterampilan Proses Sains juga sangat penting dikembangkan dalam pembelajaran fisika. Menurut Widayanto (2009) Keterampilan Proses Sains (KPS) adalah kemampuan atau kecakapan untuk melaksanakan suatu tindakan dalam belajar sains. Mengajarkan keterampilan proses pada peserta didik berarti member kesempatan kepada peserta didik untuk melakukan sesuatu bukan hanya membicarakan sesuatu, sehingga peserta didik tidak hanya sekedar memperoleh pengetahuan saja, tetapi peserta didik juga dapat menemukan pengetahuannya sendiri.

Berdasarkan hasil observasi awal bahwa diketahui hasil belajar peserta didik masih rendah dan belum maksimal dengan nilai rata-rata 60 dan KKM 70. Beberapa kekurangan dalam proses pembelajaran, terlihat pada kegiatan yang berlangsung di dalam kelas belum mengacu pada pembelajaran yang aktif, efektif, dan bermakna. Berdasarkan penjelasan di atas terlihat bahwa 
hasil belajar peserta didik kelas XI MIA 1 pada mata pelajaran fisika SMA. Negeri 1 Syamtalira Aron masih rendah.

Dengan demikian penulis ingin melakukan perbaikan dalam pembelajaran. Salah satu upaya untuk mengatasi masalah tersebut yaitu dengan menerapkan suatu model pembelajaran yang membuat pembelajaran peserta didik lebih bermakna, memberikan kesempatan peserta didik aktif dalam pembelajaran, sehingga membuat hasil belajar dan Keterampilan Proses Sains peserta didik meningkat. Menurut Ausubel (Dahar, 2011:95) belajar dikenal dengan istilah Meaningful Learning (belajar bermakna). Belajar bermakna merupakan suatu proses yang menghubungkan informasi baru pada konsep-konsep yang relevan yang terdapat dalam struktur kognitif seseorang.

Berdasarkan teori Ausubel tersebut, dapat disimpulkan pembelajaran bermakna dapat dimaknai sebagai suatu upaya yang dilakukan oleh guru untuk mengelola informasi belajar dalam kegiatan pembelajaran agar peserta didik mampu mengaitkan informasi belajar tersebut dengan informasi belajar yang telah ada dalam struktur kognitifnya atau yang telah dimilikinya.

Model yang sesuai untuk diterapkan sebagai salah satu solusi dari permasalahan yang terjadi pada peserta didik di kelas XI MIA 1 adalah model pembelajaran Learning Cycle 5E. Menurut Purniati (2009), Learning Cycle merupakan model pembelajaran yang memperhatikan kemampuan awal peserta didik. Model pembelajaran ini dikembangkan dari teori Piaget yaitu pengetahuan awal yang dimiliki peserta didik dikaitkan dengan pengetahuan baru yang diperoleh peserta didik. Learning cycle 5E merupakan rangkaian dari tahap-tahap kegiatan yang diorganisasi sehingga peserta didik dapat menguasai kompetensikompetensi yang harus dicapai dalam pembelajaran fisika dengan jalan berperan aktif (Kamdi, 2007). Model Learning Cycle 5E terdiri atas lima tahap yang saling berhubungan satu sama lainnya, yaitu pembangkitan minat (Engagement), eksplorasi (Exploration), penjelasan (Explanation), elaborasi (Elaboration), dan evaluasi (Evaluation) (Lorsbach, dalam Kamdi, 2007). Pemilihan model pembelajaran Learning Cycle 5E karena peserta didik dilibatkan secara aktif dalam proses pembelajaran sehingga keterampilan proses sains dan hasil belajar dapat meningkat, serta pembelajaran akan lebih bermakna.

Hasil penelitian Prajoso (2015) menyatakan bahwa model pembelajaran Learning Cycle tipe 5E dapat meningkatkan pemahaman konsep fisika pada peserta didik kelas X MA Al-Khairat Pusat Palu. Hasil penelitian Kulsum dan Hindarto (2011) menyatakan bahwa melalui penerapan model Learning Cycle 5E untuk sub pokok bahasan kalor peserta didik kelas VII C SMP Negeri 1 Welehan dapat meningkatkan keaktifan dan hasil belajar peserta didik tiap siklusnya. Sedangkan hasil penelitian dari Ginting (2012) menyatakan bahwa model pembelajaran Learning Cycle 5E berbasis eksperimen berpengaruh signifikan terhadap hasil belajar peserta didik pada materi pokok zat dan wujudnya.

\section{METODE}

Jenis penelitian yang digunakan yaitu penelitian tindakan kelas (PTK) dengan menggunakan pendekatan siklus. Jumlah siklus dalam penelitian ini tidak ditentukan, dalam 
pelaksanaannya penelitian ini berhasil pada siklus II sehingga penelitian ini terdiri dari II siklus. Setiap siklus memiliki 4 tahap yaitu: perencanaan, pelaksanaan tindakan, observasi, dan refleksi. Siklus pertama terdiri dari kegiatan tatap muka 6 jam pelajaran, dan siklus kedua terdiri dari 6 jam pelajaran tatap muka. Kegiatan tatap muka disesuaikan dengan rencana pembelajaran yang telah disusun terlebih dahulu.

Subjek penelitian adalah peserta didik kelas XI MIA 1 SMA Negeri 1 Syamtalira Aron tahun pelajaran 2018/2019 dengan jumlah peserta didik 30 orang. Analisis data mengenai Keterampilan Proses Sains siswa selama pembelajaran dengan menggunakan model Learning Cycle 5E disertai LKPD diperoleh dari hasil observasi. Untuk menganalisis Keterampilan Proses Sains siswa selama pembelajaran digunakan persentase Keterampilan Proses Sains siswa (Pp) dengan rumus sebagai berikut:

$$
P_{p}=\frac{P}{N} \times 100 \%
$$

Keterangan:

$\mathrm{Pp}=$ presentase KPS siswa

$\mathrm{P}=$ jumlah skor tiap indikator KPS yang diperoleh siswa

$\mathrm{N}$ = jumlah skor maksimum tiap indikator KPS siswa

Adapun kriteria Keterampilan Proses Sains terdapat pada Tabel 1. berikut ini.

Tabel 1. Kriteria Keterampilan Proses Sains Peserta Didik

\begin{tabular}{|c|c|}
\hline Interval & Kriteria \\
\hline $75 \% \leq$ Skor $<100 \%$ & Baik \\
\hline $55 \% \leq$ Skor $<75 \%$ & Cukup Baik \\
\hline $40 \% \leq$ Skor $<55 \%$ & Kurang Baik \\
\hline Skor $<40 \%$ & Tidak Baik \\
\hline
\end{tabular}

(Widayanto, 2009)

\section{HASIL DAN PEMBAHASAN}

\section{Hasil}

Hasil penelitian menunjukan bahwa keterampilan proses sains peserta didik pada materi gelombang berjalan dan gelombang stasioner dengan model pembelajaran Learning Cycle 5E mengalami peningkatan setiap siklus. Hal ini dapat dilihat pada tabel persentase keterampilan proses sains peserta didik pada siklus I dan II di bawah ini. 
Tabel 2. Persentase Keterampilan Proses Sains

\begin{tabular}{|c|c|c|}
\hline \multicolumn{2}{|c|}{ Keterampilan Proses Sains } \\
\hline Pertemuan & Siklus I & Siklus II \\
\hline 1 & $64,07 \%$ & $81,11 \%$ \\
\hline 2 & $79,26 \%$ & $91,48 \%$ \\
\hline
\end{tabular}

Berdasarkan tabel maka keterampilan proses sains siswa dalam bentuk grafik dapat dilihat sebagai berikut:

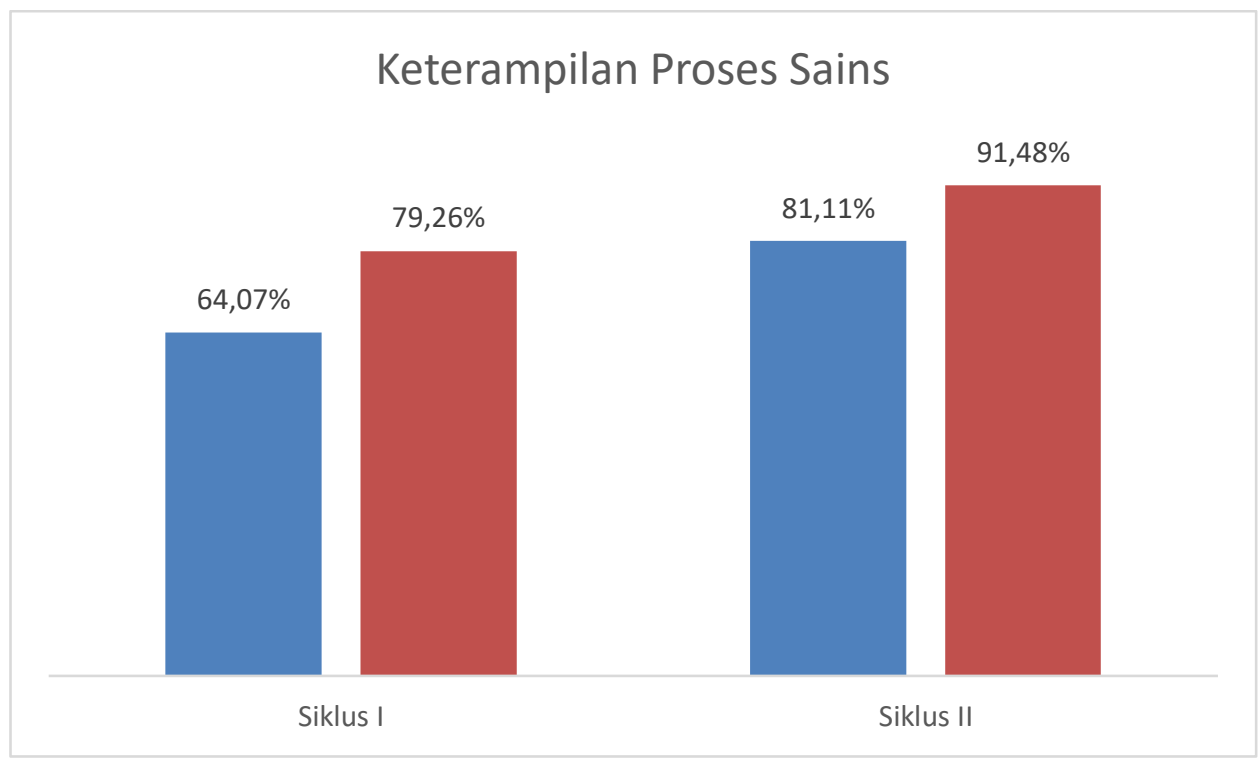

Gambar 1. Grafik Persentasi Keterampilan Proses Sains Peserta Didik

Berdasarkan table dan grafik di atas dapat diperoleh hasil sklus I pada pertemuan pertama dari ke enam aspek keterampilan proses sains yaitu mengamati, menafsirkan pengamatan, merumeskan hipotesis, menerapkan konsep, mengkomuikasikan, dan menyimpulkan, aspek ini di nilai pengamatan pada saat proses pembelajaran model Learning Cycle 5E. sedang jumlah nilai yang tercapai dari ke enam aspek 346 dan pada pertemuan kedua 428 dapat dikatakan berhasil mengajar karena ada peningkatan, sedangkan dilihat dari persentase kedua pertemuan tersebut dapat dilihat 64,07\% dan 79,26\% memperoleh peningkatan sebesar 15,19\% memiliki kriteria keterampilan proses sains pada pertemuan pertama yaitu cukup baik, sedangkan pertemuan kedua memiliki kriteria keterampilan proses sains baik.

Selanjutnya pada hasil sklus II pada pertemuan pertama dari ke enam aspek keterampilan proses sains yaitu mengamati, menafsirkan pengamatan, merumeskan hipotesis, menerapkan 
konsep, mengkomuikasikan, dan menyimpulkan, aspek ini di nilai pengamatan pada saat proses pembelajaran model Learning Cycle 5E. Sedang jumlah nilai yang tercapai dari ke enam aspek 438 dan pada pertemuan kedua 494 dapat dikatakan berhasil mengajar karena ada peningkatan, sedangkan dilihat dari persentase kedua pertemuan tersebut dapat dilihat $81,11 \%$ dan $91,48 \%$ memperoleh peningkatan sebesar 10,37\% memiliki kriteria keterampilan proses sains pada pertemuan pertama yaitu baik, sedangkan pertemuan kedua memiliki kriteria keterampilan proses sains baik.

\section{Pembahasan}

Dari hasil penelitian dilapangan yang dilaksanakan oleh peneliti dalam proses pembelajaran dengan menerapkan model pembelajaran Learning Cycle 5E di kelas XI MIA 1 SMA Negeri 1 Syamtalira Aron menunjukkan adanyan peningkatan keterampilan proses sains peserta didik sesuai dengan kriteria pada keenam aspek yaitu mengamati, menafsirkan pengamatan, merumeskan hipotesis, menerapkan konsep, mengkomuikasikan, dan menyimpulkan, pada siklus I belum sepenuhnya baik dalam mengikuti pembelajaran, karena pada pertemuan pertama siklus I memiliki kateria penilaian cukup baik. Sedangkan pada penilaian siklus I pertemuan 2 samapai dengan siklus II pertemuan 1 dan 2 mengalami peningkatan dengan kriteria baik.

\section{PENUTUP}

Berdasarkan data penelitian yang diperoleh maka dapat disimpulkan bahwa model pembelajaran Learning Cycle 5E dapat meningkatkan keterampilan proses sains peserta didik pada materi gelombang berjalan dan gelombang stasioner di kelas XI MIA 1 SMA Negeri 1 Syamtalira Aron Tahun pelajaran 2018/2019. 4. Diharapkan kepada guru yang akan melaksanakan penelitian dengan model pembelajaran Learning Cycle 5E, memiliki keterampilan dalam menciptakan suasana belajar yang baik agar waktu yang digunakan lebih efisien serta melibatkan semua anggota kelompok dalam mempresentasikan hasil kerja kelompok sehingga masing-masing anggota kelompok dapat memberikan masukan dan pendapatnya.

\section{DAFTAR PUSTAKA}

Dahar, R.W. (2011). Teori-Teori Belajar dan Pembelajaran. Jakarta: Erlangga.

Dimyati \& Mudjiono. (2006). Belajar dan Pembelajaran. Jakarta: Rineka Cipta

Ginting, E. (2012). Pengaruh Model Pembelajaran Learning Cycle Berbasis Eksperimen terhadap Hasil Belajar Siswa pada Materi Pokok Zat dan Wujudnya. Jurnal Pendidikan Fisika Unmed (25-30). 
Kamdi, W, dkk. (2007). Model-Model Inovatif. Malang: Universitas Negeri Malang.

Kulsum, U., dan Hindarto. (2011). Penerapan Model Learning Cycle pada Sub Pokok Bahasan Kalor untuk Meningkatkan Keaktifan dan Hasil Belajar Siswa Kelas VII SMP. Jurnal Pendidikan Fisika Indonesia. 7(2011): 128-133.

Magfiroh, A. (2019). Implementasi Teori Belajar Humanistik sebagai Hukum Dasar dalam Pembelajaran Pendidikan Kewarganegaraan. Jurnal Pendidikan Dan KewarganegaraanFakultas Ilmu Sosial UM.

Prajoso, D. (2015). Model Pembelajaran Learning Cycle Tipe 5e untuk Meningkatkan Pemahaman Konsep Fisika Siswa Kelas X MA Al-Khairat Pusat Palu. Jurnal Pendidikan Fisika Tadulako, 3(4):43-48.

Purniati, Tia. Sispiyati, Ririn \& Yulianti, Kartika. (2009). Penerapan Model Siklus Belajar (Learning Cycle) untuk meningkatkan Pemahaman Konsep Mahasiswa Pada Kapita Selekta. Bandung: Universitas Pendidikan Indonesia.

Widayanto. (2009). Pengembangan Keterampilan Proses dan Pemahaman Siswa Kelas X melalui Kit Optik. Jurnal Pendidikan Fisika Indonesia, 5(1). 